\title{
Substrate Acidification by Geranium: Temperature Effects
}

\author{
Matthew D. Taylor ${ }^{1}$ and Paul V. Nelson ${ }^{2,4}$ \\ Department of Horticultural Science, Campus Box 7609, North Carolina State University, \\ Raleigh, NC 27695-7609 \\ Jonathan M. Frantz ${ }^{3}$ \\ U.S. Department of Agriculture-Agricultural Research Service Application Technology Research \\ Unit, Toledo, $\mathrm{OH} 43606$
}

\begin{abstract}
AdDitional INDEX words. $\mathrm{pH}$, phosphorus, Pelargonium $\times$ hortorum, acid quantification
Abstract. Sudden pH decline (SPD) describes the situation where crops growing at an appropriate pH rapidly (within 1-2 weeks) cause the substrate pH to shift downward one to two units. 'Designer Dark Red' geraniums (Pelargonium $\times$ hortorum Bailey) were grown in three experiments to assess possible effects of temperature on SPD. The first experiment tested the effect of four day/night temperature regimes $\left(14{ }^{\circ} \mathrm{C}\right.$ day $/ 10^{\circ} \mathrm{C}$ night, $18{ }^{\circ} \mathrm{C}$ day $/ 14^{\circ} \mathrm{C}$ night, $2{ }^{\circ} \mathrm{C}$ day $/ 18^{\circ} \mathrm{C}$ night, and $26^{\circ} \mathrm{C}$ day $/ 22^{\circ} \mathrm{C}$ night) on substrate acidification. At 63 days after transplanting (DAT), substrate pH declined from 6.8 to 4.6 as temperature increased. Tissue phosphorus $(P)$ of plants grown at the highest three temperatures was extremely low $(0.10 \%-0.14 \%$ of dry weight), and $P$ stress has been reported to cause acidification. It was not possible to determine if the drop in substrate $\mathrm{pH}$ was a singular temperature effect or a combination of high temperature and low $P$. To resolve this, a second experiment tested a factorial combination of the three highest temperatures from the first experiment and five preplant $P$ rates $\left(0,0.065,0.13,0.26\right.$, or $0.52 \mathrm{~g} \cdot \mathrm{L}^{-1}$ substrate). Regardless of tissue $P$ concentrations, which ranged from deficient to above adequate, substrate $\mathrm{pH}$ decreased with increasing temperature. At $63 \mathrm{DAT}$, in the 0.065 and $0.13 \mathrm{P}$ treatments, tissue $P$ was deficient and pH decreased with increasing temperature from 5.6 to 4.7 and 5.9 to 4.7 , respectively. In the $0.26 \mathrm{P}$ treatment, tissue $P$ was adequate at the lowest temperature and there was no acidification. At the mid- and highest temperatures, tissue $P$ was deficient and statistically equivalent, yet $\mathrm{pH}$ decreased to 5.2 and 4.7 , respectively. In the highest $P$ treatment, tissue $P$ levels were unaffected by temperature, above adequate, and $\mathrm{pH}$ declined with each increase in temperature from 6.5 to 5.0. The results at 63 DAT once more showed that temperature acted independent of tissue $P$ and caused geraniums to acidify the substrate. In the third experiment, the amount of acidity produced by roots of plants grown at the two highest temperatures used in the first two experiments was quantified. Plants grown at the higher temperature produced $28 \%$ more acid per gram dry root. The results herein indicate that high temperature can induce SPD by geranium.
\end{abstract}

During the 1980s, many geranium producers observed a sporadic, unexplained decline in substrate $\mathrm{pH}$. During the same time period, they also reported the occurrence of toxic concentrations of Fe or Mn in leaf tissue (Bachman and Miller, 1995). In organic-based soil-less substrate, $\mathrm{pH}$ has a large affect on nutrient availability (Nelson, 2003). As $\mathrm{pH}$ decreases, most micronutrients become more available and can become toxic. In a study with 'Ringo Scarlet' geraniums, dry tissue Fe, Mn, and $\mathrm{Zn}$ concentration increased from 82 to 951,118 to 9260 , and 56 to $1340 \mathrm{mg} \cdot \mathrm{kg}^{-1}$, respectively, as final substrate $\mathrm{pH}$ decreased from $\approx 6.5$ to $\approx 5.5$ (Lee et al., 1996). The symptoms of micronutrient toxicity in geranium include reduced leaf and plant size; black spots on young leaves; dark green color, large

Received for publication 7 Dec. 2007. Accepted for publication 2 Apr. 2008. Mention of a trademark, proprietary product, or vendor does not constitute a guarantee or warranty of the product by the U.S. Dept. of Agriculture and does not imply its approval to the exclusion of other products or vendors that also may be suitable.

The authors gratefully acknowledge the scientists and staff of the North Carolina State University Phytotron; Ball Floraplant, Will Healy, and Kristan McGuigan for providing incite and plant material; and Nancy Mingus, Elizabeth Taylor, Douglas Sturtz, and Elisa Ruszkiewicz for technical assistance.

${ }^{1}$ Graduate research assistant

${ }^{2}$ Professor.

${ }^{3}$ Research Horticulturist.

${ }^{4}$ Corresponding author. E-mail: paul_nelson@ncsu.edu. purplish or black spots, leaf cupping, and interveinal, marginal, or speckled chlorosis on the entire plant; cupping, and interveinal, marginal, or speckled chlorosis or necrosis on older leaves; and in severe cases, complete necrosis of older leaves (Bachman and Miller, 1995; Broschat and Moore, 2004; Lee et al., 1996; Smith et al., 2004).

Sudden $\mathrm{pH}$ decline (SPD) describes the situation where crops growing at an appropriate $\mathrm{pH}$ rapidly (within 1-2 weeks) cause the substrate $\mathrm{pH}$ to shift downward one to two units. Within a greenhouse firm or geographic area, one geranium crop may be affected, whereas the subsequent crops are not, although all crops appear to be grown similarly. Geraniums are the highest valued bedding plant of the $\$ 2.53$ billion bedding plant industry (USDA, 2005) and SPD can cause severe economic loses or lead to tedious $\mathrm{pH}$ adjustments, such as application of flowable lime. The cause of SPD is unknown.

Apparently, an unknown signal(s) triggers an acidification process by roots. Three nutrient deficiencies known to cause plants to acidify substrate include: Fe (Welkie and Miller, 1993), Zn (Cakmak and Marschner, 1990), and P (Schjorring, 1986; Hinsinger, 2001). Pea (Pisum sativum L.), sugar beet (Beta vulgaris L.), and bean (Phaseolus vulgaris L.) lowered root substrate $\mathrm{pH}$ from around 7.0 to 4.0 in 6 to $10 \mathrm{~h}$ when $\mathrm{Fe}$ was missing in the nutrient solution (Landsberg, 1981). The drop occurred in a $\mathrm{NO}_{3}{ }^{-} \mathrm{N}$ solution that normally causes the substrate $\mathrm{pH}$ to rise. Zinc deficiency has also been shown to 
cause acidification in dicotyledonous species even when $\mathrm{NO}_{3}$ was the sole source of $\mathrm{N}$ (Cakmak and Marschner, 1990). However, it is unlikely that $\mathrm{Fe}$ or $\mathrm{Zn}$ deficiency is the cause of SPD because both nutrients are applied sufficiently by most growers and the syndrome typically leads to $\mathrm{Fe}$ toxicity, not deficiency. On the other hand, P deficiency seems a likely contributor to the induction of SPD because growers rely heavily on alkaline fertilizers to offset $\mathrm{pH}$ decline, particularly in geranium, and $\mathrm{P}$ is low or absent in these alkaline fertilizers; i.e., $13 \mathrm{~N}-0.9 \mathrm{P}-10.8 \mathrm{~K}, 15 \mathrm{~N}-0 \mathrm{P}-12.5 \mathrm{~K}$, and $14 \mathrm{~N}-0 \mathrm{P}-11.6 \mathrm{~K}$ (Nelson, 2003).

In addition to low $\mathrm{P}$, there is evidence high temperature might also contribute to the occurrence of SPD. Micronutrient toxicity symptoms have been reported to be more common after high temperature stress (Smith et al., 2004). Taylor et al. (2007) showed that geraniums grown at $26^{\circ} \mathrm{C}$ day $/ 22^{\circ} \mathrm{C}$ night required more base to maintain hydroponic solution $\mathrm{pH}$ than plants grown at $22{ }^{\circ} \mathrm{C}$ day $/ 18{ }^{\circ} \mathrm{C}$ night, indicating increased acidification. The objectives of this research were to determine if high temperature causes geraniums to acidify the substrate (Expt. 1), if the temperature effect is independent of tissue $\mathrm{P}$ concentration (Expt. 2), and to quantify the amount of acidity produced due to high temperature and $\mathrm{P}$ stress in hydroponics (Expt. 3).

\section{Materials and Methods}

EXPT. 1. Rooted 'Designer Dark Red' (zonal) and 'Galleria Bright Violet' (ivy) geranium cuttings were fumigated for insects overnight with $0.5 \%$ Bifenthrin (Attain TR; Whitmire Micro-Gen Research Laboratories, St. Louis), planted the following day into $11-\mathrm{cm}$-diameter $\left(606 \mathrm{~cm}^{3}\right)$ azalea pots, and grown for $63 \mathrm{~d}$. The substrate consisted of 3:1 by volume peat:perlite amended with $\mathrm{MgSO}_{4}$, Micromax micronutrient mix (The Scotts Co., Marysville, $\mathrm{OH}$ ), triple-superphosphate $(19.7 \% \mathrm{P})$ at $0.59,0.89$, and $0.26 \mathrm{~g} \cdot \mathrm{L}^{-1}$ substrate, respectively, and flowable dolomitic limestone (Cleary Chemical Corp., Dayton, NJ) at $8.34 \mathrm{~mL} \cdot \mathrm{L}^{-1}$ substrate. Treatments were arranged in a factorial design with four temperature regimes $\left(14{ }^{\circ} \mathrm{C}\right.$ day $/ 10^{\circ} \mathrm{C}$ night, $18{ }^{\circ} \mathrm{C}$ day $/ 14{ }^{\circ} \mathrm{C}$ night, $22^{\circ} \mathrm{C}$ day $/ 18^{\circ} \mathrm{C}$ night, and $26{ }^{\circ} \mathrm{C}$ day $/ 22{ }^{\circ} \mathrm{C}$ night), and two cultivars. There were three replications and two single-plant pots per plot, giving a total of 48 plants. Plants were grown in growth chambers with $9 \mathrm{~m}^{2}$ of growing area and $2.13 \mathrm{~m}$ vertical clearance in the Phytotron at North Carolina State University. The light regime consisted of a 9-h photosynthetic light period, $6 \mathrm{~h}$ of darkness, a 3-h low-light night interruption, and $6 \mathrm{~h}$ of darkness. During the photosynthetic period, cool white fluorescent and incandescent lamps separated from the growing area by a polycarbonate barrier supplied a photosynthetic photon flux $(P P F)$ of $575 \pm 25 \mu \mathrm{mol} \cdot \mathrm{m}^{-2} \cdot \mathrm{s}^{-1}$. The 3-h low-light night interruption was provided by incandescent lamps and supplied a $P P F$ of $25 \mu \mathrm{mol} \cdot \mathrm{m}^{-2} \cdot \mathrm{s}^{-1}$. Carbon dioxide concentrations were maintained between 300 and $400 \mu \mathrm{L} \cdot \mathrm{L}^{-1}$ by controlled injection of commercial grade gas. Plants were fertilized with each irrigation with a solution made from

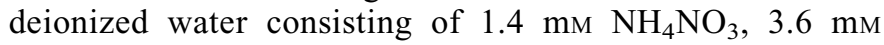
$\mathrm{Ca}\left(\mathrm{NO}_{3}\right)_{2}$, and $4 \mathrm{~mm} \mathrm{KNO}_{3}(\mathrm{~N}, \mathrm{~K}$, and $\mathrm{Ca}$ at 196,156 , and $144 \mathrm{mg} \cdot \mathrm{L}^{-1}$, respectively). Plants were fertigated when the substrate was dry.

Expт. 2. This experiment was similar to Expt. 1 except it had one cultivar ('Designer Dark Red'), three temperature treatments $\left(18^{\circ} \mathrm{C}\right.$ day $/ 14^{\circ} \mathrm{C}$ night, $22^{\circ} \mathrm{C}$ day $/ 18^{\circ} \mathrm{C}$ night, and $26^{\circ} \mathrm{C}$ day $/ 22{ }^{\circ} \mathrm{C}$ night), five $\mathrm{P}$ treatments $(0,0.065,0.13,0.26$, and $0.52 \mathrm{~g} \cdot \mathrm{L}^{-1}$ substrate), and two harvest dates. Three replications gave a total of 90 plants. Lime in the substrate was $\mathrm{CaCO}_{3}$ powder (Fisher Scientific, Pittsburgh, PA) supplied at $3.5 \mathrm{~g} \cdot \mathrm{L}^{-1}$ substrate because the flowable dolomitic limestone caused substrate $\mathrm{pH}$ to rise for the first 5 weeks during Expt. 1 (Fig. 1).


Fig. 1. Substrate $\mathrm{pH}$, every $7 \mathrm{~d}$ after transplanting (DAT) for 'Designer Dark Red' (A) and 'Galleria Bright Violet' (B) geraniums at extra-low $\left(14{ }^{\circ} \mathrm{C}\right.$ day/ $10{ }^{\circ} \mathrm{C}$ night $)$, low $\left(18{ }^{\circ} \mathrm{C}\right.$ day $/ 14^{\circ} \mathrm{C}$ night $)$, medium $\left(22^{\circ} \mathrm{C}\right.$ day $/ 18^{\circ} \mathrm{C}$ night $)$, and high $\left(26^{\circ} \mathrm{C}\right.$ day $/ 22^{\circ} \mathrm{C}$ night $)$ temperatures in Expt. 1. Error bars represent $\mathrm{SE}(\mathrm{n}=3)$. On the right side of each temperature curve are the tissue dry weight percentages of $\mathrm{P}$ at 63 DAT. Mean separation by Duncan's multiple range test at $P \leq 0.05$. 
EXPTS. 1 AND 2 measurements. Substrate $\mathrm{pH}$ was measured via the pour-through technique (Wright, 1986) every $7 \mathrm{~d}$ for the length of both experiments, and immediately after each pourthrough, plants were fertilized. In Expt. 2, pour-through extracts taken 14, 28, 42, and 56 DAT were also analyzed for P. At 63 DAT in Expt. 1 and at 28 and 63 DAT in Expt. 2, four to six recently mature leaves were removed from one plant, rinsed with $0.1 \mathrm{~N} \mathrm{HCl}$, and rinsed again with deionized water. Plant samples from all three experiments were dried in a forced-air oven at $60^{\circ} \mathrm{C}$ for $48 \mathrm{~h}$, weighed, ground in a Wiley mill through a 25-mesh screen (1-mm particle size), and the $P$ content of both leaf samples and pour-through extracts were determined with inductively coupled plasma optical emission spectroscopy (IRIS-Intrepid II; Thermo Fischer Scientific, Waltham, MA). Pour-though $\mathrm{P}$ concentrations could not be detected below the lower limit of $11 \mu \mathrm{g} \cdot \mathrm{L}^{-1}$. All tissue concentrations are expressed on a dry weight basis. Experimental data were statistically analyzed as a complete block design with mean separation by Duncan's multiple range test at $P=0.05$ using SAS (version 9.1; SAS Institute, Cary, NC). Interactions were considered significant at $P \leq 0.05$. In Expt. 2, the low temperature treatments were used for regression analysis of substrate $\mathrm{pH}$ over the time period 35 to 63 DAT using Excel (Microsoft Office 2007; Microsoft Corp., Redmond, WA).

EXPT. 3. 'Designer Dark Red' geranium cuttings, partially rooted in Oasis ${ }^{\circledR}$ Wedge ${ }^{\circledR}$ growing foam (Smithers-Oasis North America, Kent, $\mathrm{OH}$ ), were fumigated overnight as in Expts. 1 and 2 . The following day they were placed in the same type of growth chambers used in Expts. 1 and 2. The temperature was $22 / 18{ }^{\circ} \mathrm{C}$ day/night and plants were fertilized daily with a complete fertilizer containing $\mathrm{N}, \mathrm{P}, \mathrm{K}, \mathrm{Ca}, \mathrm{Mg}, \mathrm{Fe}, \mathrm{S}, \mathrm{Mn}, \mathrm{B}$, $\mathrm{Zn}, \mathrm{Cu}, \mathrm{Mo}$, and $\mathrm{Na}$ at 106, 10, 111, 54, 12, 5, 13, 0.1, 0.2, 0.01, $0.005,0.005$, and $11 \mathrm{mg} \cdot \mathrm{L}^{-1}$, respectively. After $14 \mathrm{~d}, 96$ rooted cuttings were transplanted into 12 plastic containers measuring $27 \times 32 \mathrm{~cm}$ and $22 \mathrm{~cm}$ tall. Containers were covered with plastic lids with eight evenly spaced $2.5-\mathrm{cm}$ holes to hold plants. Half of the containers were placed in a second growth chamber set to a day/night temperature of $26 / 22^{\circ} \mathrm{C}$. The hydroponic containers were aerated and filled with $19 \mathrm{~L}$ of solution consisting of $1.5 \mathrm{~mm} \mathrm{NH}_{4} \mathrm{NO}_{3}, 5 \mathrm{~mm} \mathrm{Ca}\left(\mathrm{NO}_{3}\right)_{2}, 2 \mathrm{~mm} \mathrm{KNO}{ }_{3}, 1 \mathrm{~mm} \mathrm{KH} \mathrm{KO}_{4}$ ( $0 \mathrm{~mm}$ in minus $\mathrm{P}$ treatment), $1.5 \mathrm{~mm} \mathrm{KCl}$ (2.5 mM in minus $\mathrm{P}$ treatment), $2 \mathrm{~mm} \mathrm{MgSO}_{4}, 69 \mu \mathrm{M} \mathrm{Fe}$ as Fe-DTPA, 9.1 $\mu \mathrm{M}$ $\mathrm{MnSO}_{4} \cdot \mathrm{H}_{2} \mathrm{O}, 0.76 \mu \mathrm{M} \mathrm{ZnSO}_{4} \cdot 7 \mathrm{H}_{2} \mathrm{O}, 46.3 \mu \mathrm{M} \mathrm{H}_{3} \mathrm{BO}_{3}, 1.57 \mu \mathrm{M}$ $\mathrm{CuSO}_{4} \cdot 5 \mathrm{H}_{2} \mathrm{O}$, and $0.10 \mu \mathrm{M} \mathrm{Na} \mathrm{MoO}_{4} \cdot 2 \mathrm{H}_{2} \mathrm{O}$. The volume of the containers was maintained at $19 \mathrm{~L}$ and the $\mathrm{pH}$ was set and maintained at 5.80 by additions of $5 \mathrm{~mm} \mathrm{Ca}(\mathrm{OH})_{2}$.

This experiment was a factorial design with two temperature treatments $\left(22^{\circ} \mathrm{C}\right.$ day $/ 18^{\circ} \mathrm{C}$ night and $26{ }^{\circ} \mathrm{C}$ day $/ 22^{\circ} \mathrm{C}$ night $)$, two $\mathrm{P}$ treatments $(0$ and $1 \mathrm{~mm} \mathrm{P})$, and three sampling dates $(7$, 13 , and 19 DAT) with three replicates, and two plants per plot. On each sampling date, at $\approx 1200 \mathrm{HR}$, two plants were removed from each hydroponic unit. Each plant was placed into a glass $500-\mathrm{mL}$ beaker containing an aerated solution ( $\mathrm{pH}$ of 5.80), identical to the solution in the 19-L units from which they were transplanted. The beakers were located within the same growth chamber and had polycarbonate lids that held the plants. After $24 \mathrm{~h}$, plants were removed and roots were rinsed with deionized water so that all solution remaining on roots was washed back into the beaker. Plants were then separated into roots and shoots. Roots were dipped in $1 \mathrm{~mm} \mathrm{CaSO}_{4}$ for $30 \mathrm{~s}$ followed by deionized water to remove ions from the apoplast (Naegle et al., 2005), patted dry, and weighed. Shoots were weighed, rinsed with $0.1 \mathrm{~N} \mathrm{HCl}$, rinsed again with deionized water, and then roots and shoots were dried as previously described and weighed again. All leaves with petioles were removed from stems for shoot tissue analysis as described previously. Roots were also analyzed. Solutions in beakers were brought back to volume $(500 \mathrm{~mL})$ with deionized water and titrated with a standardized base to the initial $\mathrm{pH}$ of 5.80 to determine the amount of acid produced by roots.

\section{Results}

EXPT. 1. For all temperature treatments and both cultivars, $\mathrm{pH}$ increased from less than 5.1 to greater than 6.2 during the first $35 \mathrm{~d}$ (Fig. 1). This is thought to be a consequence of the unexpected slow dissolution of the preplant flowable dolomitic limestone. All interactions were significant for substrate $\mathrm{pH}$, tissue percentage of $\mathrm{P}$, and shoot dry weight. Starting 49 DAT for both geranium cultivars, substrate $\mathrm{pH}$ decreased as temperature increased. By $63 \mathrm{DAT}$, substrate $\mathrm{pH}$ of plants grown at low $\left(18{ }^{\circ} \mathrm{C}\right.$ day $/ 14{ }^{\circ} \mathrm{C}$ night $)$, medium, $\left(22^{\circ} \mathrm{C}\right.$ day $/ 18^{\circ} \mathrm{C}$ night $)$, and high $\left(26^{\circ} \mathrm{C}\right.$ day $/ 22^{\circ} \mathrm{C}$ night $)$ temperatures had decreased to $6.18,5.49$, and 4.53, respectively, for 'Designer Dark Red' and 6.40, 5.77, and 4.76 for 'Galleria Bright Violet'. Leaf P concentration of both cultivars were significantly higher in plants that were grown at the extra-low temperature $\left(14^{\circ} \mathrm{C}\right.$ day/ $10{ }^{\circ} \mathrm{C}$ night) compared with all other temperature treatments, which were similar (Fig. 1). Krug et al. (2006) determined that the lower end of the acceptable range for tissue dry weight $\mathrm{P}$ concentration in recently mature leaves for mature zonal geraniums is $0.17 \%$ to $0.19 \%$. This indicates that all geraniums, other than those grown at extra-low temperature, were approaching or experiencing $\mathrm{P}$ deficiency. Phosphorus deficiency was expressed as interveinal and marginal yellowing and reddening of lower leaves. Shoot dry weights of plants grown at high temperature were significantly higher than plants grown at all other temperature treatments, and the opposite occurred for plants grown at extra-low temperature, for both cultivars (Table 1). The number of irrigations required increased with temperature for Expts. 1 and 2 (Table 2).

Expт. 2. All interactions were significant for $\mathrm{pH}$ and tissue $\mathrm{P}$ concentration (Fig. 2). Substrate $\mathrm{pH}$ generally decreased as temperature increased with all P treatments, starting 28 DAT. Differences in substrate $\mathrm{pH}$ between temperature treatments generally increased over time and were greatest with the three highest $\mathrm{P}$ treatments, 63 DAT. Substrate $\mathrm{pH}$ of plants grown with zero $\mathrm{P}$ decreased with increasing temperature starting

Table 1. Effect of temperature treatment on shoot dry weight for 'Designer Dark Red' and 'Galleria Bright Violet' geraniums 63 $\mathrm{d}$ after transplanting in Expt. 1.

\begin{tabular}{|c|c|c|}
\hline \multirow{4}{*}{$\begin{array}{l}\text { Temperature } \\
\text { treatment (day/night) }\end{array}$} & \multicolumn{2}{|c|}{ Cultivar } \\
\hline & Designer & Galleria \\
\hline & Dark Red & Bright Viol \\
\hline & \multicolumn{2}{|c|}{--------------Dry wt (g)------------- } \\
\hline Extra-low $\left(14 / 10^{\circ} \mathrm{C}\right)$ & $10.3 c^{z}$ & $5.8 \mathrm{~d}$ \\
\hline Low $\left(18 / 14{ }^{\circ} \mathrm{C}\right)$ & $22.4 \mathrm{~b}$ & $13.2 \mathrm{c}$ \\
\hline Medium $\left(22 / 18^{\circ} \mathrm{C}\right)$ & $23.5 \mathrm{~b}$ & $18.1 \mathrm{~b}$ \\
\hline $\operatorname{High}\left(26 / 22^{\circ} \mathrm{C}\right)$ & $25.4 \mathrm{a}$ & $20.8 \mathrm{a}$ \\
\hline
\end{tabular}

${ }^{\mathrm{z}}$ Mean separation by Duncan's multiple range test within columns at $P \leq 0.05$. 
Table 2. Number of irrigations applied to geranium plants in the extralow, low, medium, and high temperature treatments in Expts. 1 and 2.

\begin{tabular}{lcc}
\hline Temperature & Expt. 1 & Expt. 2 \\
\cline { 2 - 3 } treatment $($ day/night $)$ & \multicolumn{2}{c}{ Irrigations (no.) } \\
\hline Extra-low $\left(14 / 10^{\circ} \mathrm{C}\right)$ & 25 & - \\
Low $\left(18 / 14{ }^{\circ} \mathrm{C}\right)$ & 34 & 21 \\
Medium $\left(22 / 18^{\circ} \mathrm{C}\right)$ & 37 & 27 \\
High $\left(26 / 22{ }^{\circ} \mathrm{C}\right)$ & & 33 \\
\hline
\end{tabular}
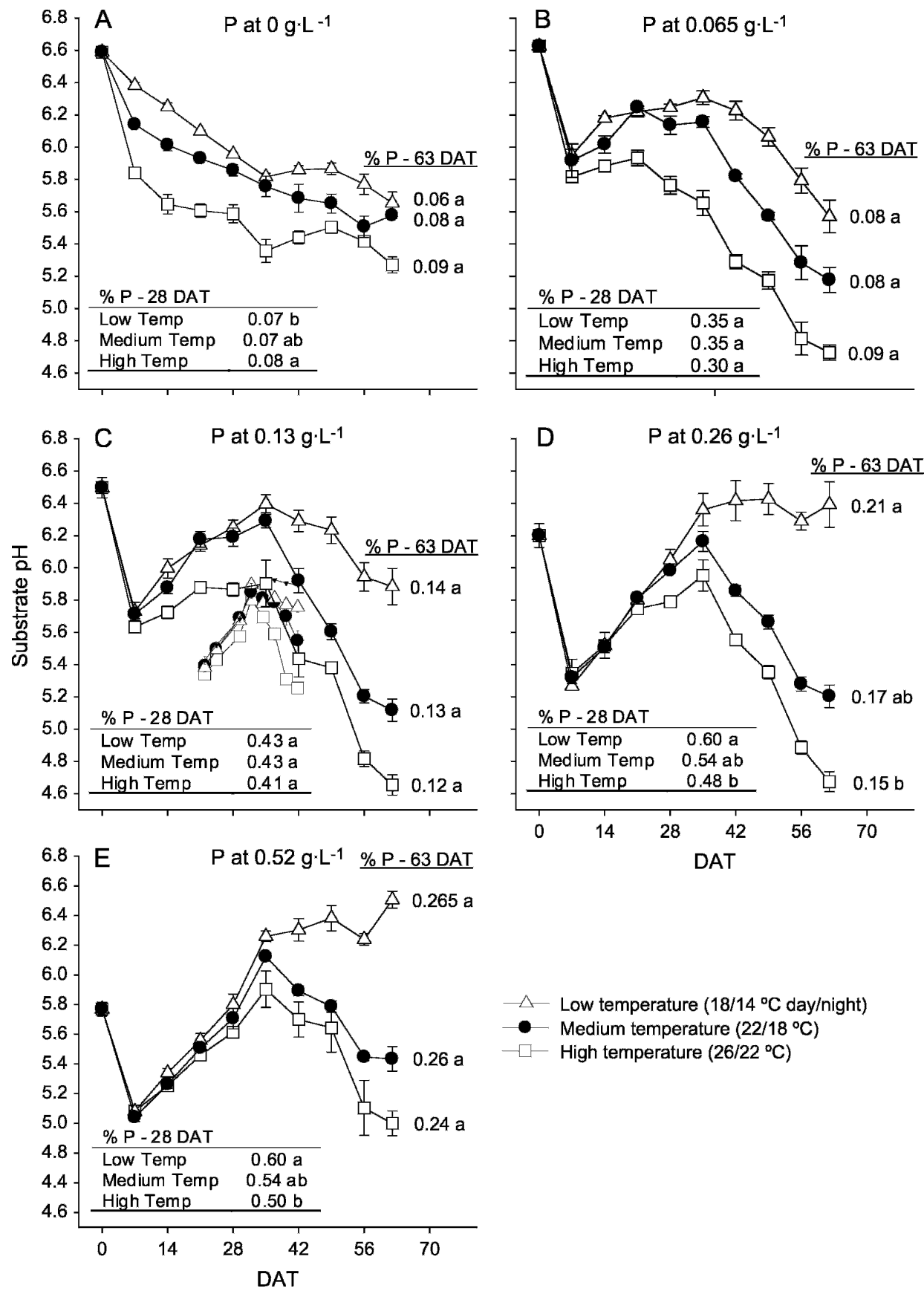

Fig. 2. Substrate $\mathrm{pH}$, measured initially and every $7 \mathrm{~d}$ after transplanting geraniums (DAT), for each preplant rate of $\mathrm{P}$ in substrate $\left[(\mathbf{A}) 0,(\mathbf{B}) 0.065\right.$, (C) 0.13 , (D) 0.26 , and (E) $0.52 \mathrm{~g} \cdot \mathrm{L}^{-1}$ substrate] at low $\left(18{ }^{\circ} \mathrm{C}\right.$ day $/ 14{ }^{\circ} \mathrm{C}$ night), medium $\left(22{ }^{\circ} \mathrm{C}\right.$ day $/ 18{ }^{\circ} \mathrm{C}$ night $)$, and high $\left(26^{\circ} \mathrm{C}\right.$ day $/ 22{ }^{\circ} \mathrm{C}$ night $)$ temperatures in Expt.2. Error bars represent SE $(n=3)$. In the lower left corner of each $\mathrm{P}$ treatment graph is a table with tissue dry weight percentages of P 28 DAT for that particular P treatment at each temperature. On the right side of each temperature curve is the tissue dry weight percentage of P at 63 DAT. Mean separation by Duncan's multiple range test at $P \leq 0.05$.
7 DAT and decreased over time. At 63 DAT in the 0.065 and $0.13 \mathrm{P}$ treatments, substrate $\mathrm{pH}$ decreased with increasing temperature from 5.6 to 4.7 and 5.9 to 4.7 , respectively. At the two highest $\mathrm{P}$ rates, the temperature effects on substrate $\mathrm{pH}$ were statistically significant starting 35 DAT, and by 63 DAT, differences were greater than $1.5 \mathrm{pH}$ units.

When comparing all low-temperature-grown plants, the slope of substrate $\mathrm{pH}$ was negative for plants that had end-ofcrop tissue $\mathrm{P}$ concentration below 0.20 and was zero or positive when tissue $\mathrm{P}$ was greater than 0.20 , starting 35 DAT (Table 3 ). The $P$ value of the slope was highly significant and the $r^{2}$ as well correlated when $P$ was supplied but deficient. In the zero $\mathrm{P}$ treatment, the rate of $\mathrm{pH}$ decline began to subside at 35 DAT. These data indicate that $\mathrm{P}$ deficiency of geraniums can cause substrate acidification.

Tissue $\mathrm{P}$ was adequate and ranged from $0.30 \%$ to $0.60 \%$ with all temperature and $\mathrm{P}$ treatments (except 0 P) at 28 DAT in Expt. 2 (Fig. 2). At the end of the crop, tissue $\mathrm{P}$ was deficient and less than $0.15 \%$ in all plants grown with the three lowest $\mathrm{P}$ rates. Plants grown with $0.26 \mathrm{~g}$ of $\mathrm{P}$ had end of crop tissue $\mathrm{P}$ concentrations that were at or just below adequate and plants grown at the highest $\mathrm{P}$ rate had tissue $\mathrm{P}$ above adequate $(>0.20)$. Temperature treatments did not significantly effect tissue $\mathrm{P}$ concentration except when plants were grown with $0.26 \mathrm{~g}$ of $P$.

The only interaction that was significant for $\mathrm{P}$ concentration of substrate-pour-through-extracts was $\mathrm{P}$ rate $\times \mathrm{DAT}$, and the temperature effect was nonsignificant (Fig. 3). As expected, substrate extract P concentrations increased significantly as $P$ rate increased, at 14 DAT. The concentration of $\mathrm{P}$ decreased over time for all $\mathrm{P}$ treatments except the zero treatment, which was nondetectable on all sampling dates.

In Expt. 2, plants grown at low temperature weighed significantly less than plants grown at medium and high temperature, at 28 DAT (Table 4). High-temperature-grown plants weighed significantly less than all other plants at 63 DAT. These data indicate that plants may have been under high temperature stress, which was not apparent in Expt. 1. Plants that did not receive $P$ weighed less than all other plants on both dates. At 63 DAT, plants from the $0.065 \mathrm{P}$ treatment weighed less 
Table 3. Effect of preplant $\mathrm{P}$ rate on tissue dry weight percentage of $\mathrm{P}$ $63 \mathrm{~d}$ after transplanting (DAT) for geranium plants grown at low temperature, and the corresponding $r^{2}$ value, slope, and slope $P$ value for DAT (x-axis) versus $\mathrm{pH}$ (y-axis) trend line (not shown, see Fig. 2) starting 35 DAT in Expt. 2.

\begin{tabular}{lccrc}
\hline P rate $\left(\mathrm{g} \cdot \mathrm{L}^{-1}\right.$ substrate $)$ & $\mathrm{P}(\%)$ & $r^{2}$ & Slope & $P$ value \\
\hline 0 & $0.06 \mathrm{~d}^{\mathrm{z}}$ & 0.32 & -0.01 & 0.0292 \\
0.065 & $0.08 \mathrm{~d}$ & 0.85 & -0.02 & $<0.001$ \\
0.13 & $0.14 \mathrm{c}$ & 0.70 & -0.03 & $<0.001$ \\
0.26 & $0.21 \mathrm{~b}$ & 0.00 & 0.00 & 0.841 \\
0.52 & $0.26 \mathrm{a}$ & 0.20 & 0.01 & 0.091
\end{tabular}

${ }^{\mathrm{z}}$ Mean separation by Duncan's multiple range test at $P \leq 0.05$.

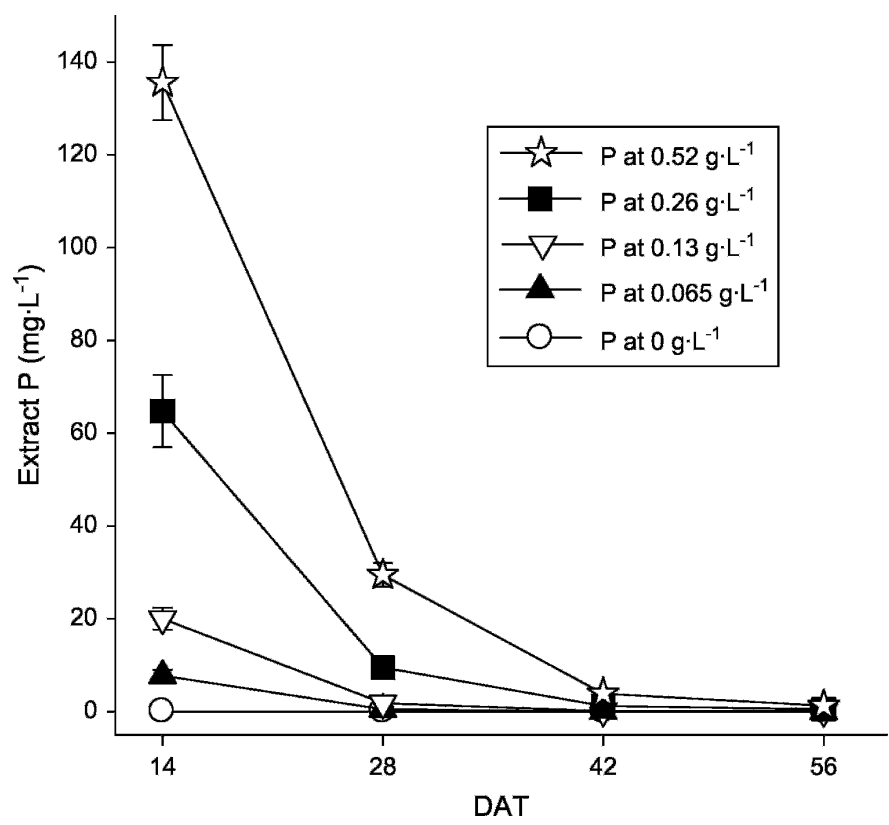

Fig. 3. Pour-through extract $\mathrm{P}$ concentration at $14,28,42$, and $56 \mathrm{~d}$ after transplanting geraniums (DAT) for treatments receiving $\mathrm{P}$ at $0,0.065,0.13$, 0.26 , and $0.52 \mathrm{~g} \cdot \mathrm{L}^{-1}$ substrate. Error bars represent SE $(\mathrm{n}=9)$. Temperature treatments were combined.

Table 4. Main effects of temperature treatment and $\mathrm{P}$ rate on geranium plant dry weights 28 and $63 \mathrm{~d}$ after transplanting (DAT) for Expt. 2.

\begin{tabular}{llc}
\hline & \multicolumn{2}{c}{ DAT } \\
\cline { 2 - 3 } & 28 & 63 \\
\hline Temperature treatment (day/night) & ----- Dry wt $(\mathrm{g})------$ \\
$\quad$ Low $\left(18 / 14^{\circ} \mathrm{C}\right)$ & $2.54 \mathrm{~b}^{\mathrm{z}}$ & $13.05 \mathrm{a}$ \\
Medium $\left(22 / 18^{\circ} \mathrm{C}\right)$ & $3.84 \mathrm{a}$ & $13.82 \mathrm{a}$ \\
High $\left(26 / 22^{\circ} \mathrm{C}\right)$ & $3.67 \mathrm{a}$ & $11.73 \mathrm{~b}$ \\
P rate $\left(\mathrm{g} \cdot \mathrm{L}^{-1}\right.$ substrate) & & \\
0 & $1.51 \mathrm{~b}$ & $1.49 \mathrm{~d}$ \\
0.065 & $3.44 \mathrm{a}$ & $13.78 \mathrm{c}$ \\
0.13 & $3.95 \mathrm{a}$ & $15.47 \mathrm{~b}$ \\
0.26 & $4.06 \mathrm{a}$ & $16.45 \mathrm{ab}$ \\
0.52 & $3.78 \mathrm{a}$ & $17.15 \mathrm{a}$
\end{tabular}

${ }^{\mathrm{z}}$ Mean separation by Duncan's multiple range test within columns at $P \leq 0.05$. than all plants receiving higher $P$ rates and plants from the 0.13 $P$ treatment weighed significantly less than plants from the 0.52 $P$ treatment.

EXPT. 3. Shoot and root $P$ concentrations were lower in plants that did not receive $\mathrm{P}$ on all sampling dates, and all interactions were significant (Fig. 4). Shoot P was deficient 7 DAT and decreased over time in plants that did not receive $P$. Among plants grown with $\mathrm{P}$, plants grown at high temperature had higher root tissue P 11 and 19 DAT, higher shoot P 7 DAT, and lower shoot P 19 DAT than plants grown at the control temperature. The amount of acid produced per gram dry weight of root was $23.6 \mathrm{mmol}$ from plants grown at high $\left(26^{\circ} \mathrm{C}\right.$ day $/ 22^{\circ} \mathrm{C}$ night) temperature and $18.4 \mathrm{mmol}$ from plants grown at the control $\left(22{ }^{\circ} \mathrm{C}\right.$ day $/ 18{ }^{\circ} \mathrm{C}$ night $)$ temperature. This difference

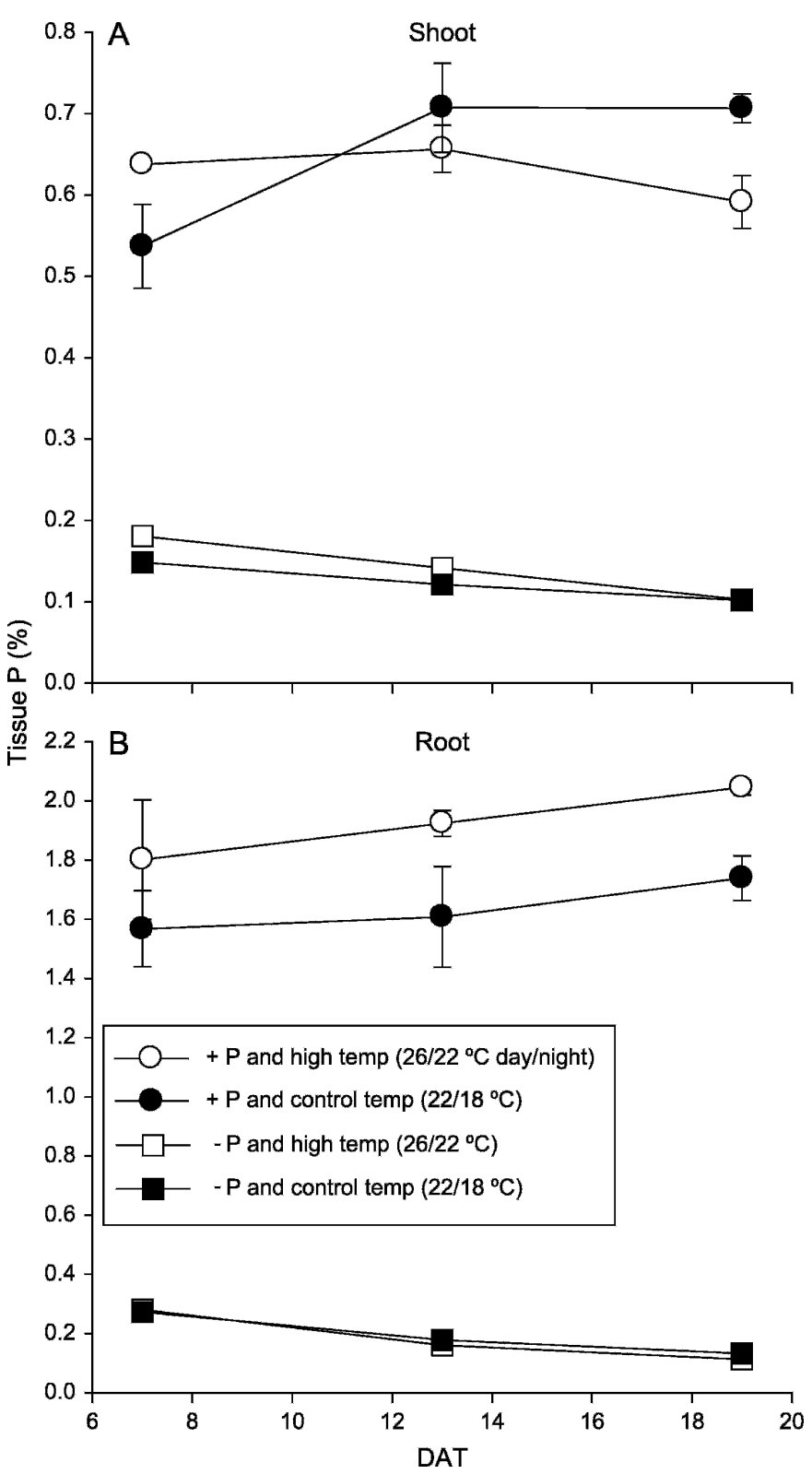

Fig. 4. Shoot (A) and root (B) tissue P concentration (percentage of dry weight) at 7,13 , and $19 \mathrm{~d}$ after transplanting (DAT) in geranium plants grown at control $\left(22^{\circ} \mathrm{C}\right.$ day $/ 18^{\circ} \mathrm{C}$ night $)$ and high $\left(26^{\circ} \mathrm{C}\right.$ day $/ 22^{\circ} \mathrm{C}$ night $)$ temperatures with $(+\mathrm{P})$ and without $\mathrm{P}(-\mathrm{P})$. Error bars represent $\mathrm{SE}(\mathrm{n}=3)$. 
was significant at $P=0.025$ and is a $28.3 \%$ increase in acid production at high temperature. There was an interactive effect of $\mathrm{P}$ treatment and DAT on acid production. Acid production did not differ 7 DAT, but at 13 and 19 DAT, acid production by roots of P-deficient plants was less than plants that received $\mathrm{P}$ (Fig. 5). The dry weights of plants was unaffected by temperature, but was lower due to lack of $\mathrm{P}$, and this difference increased over time (Fig. 6).

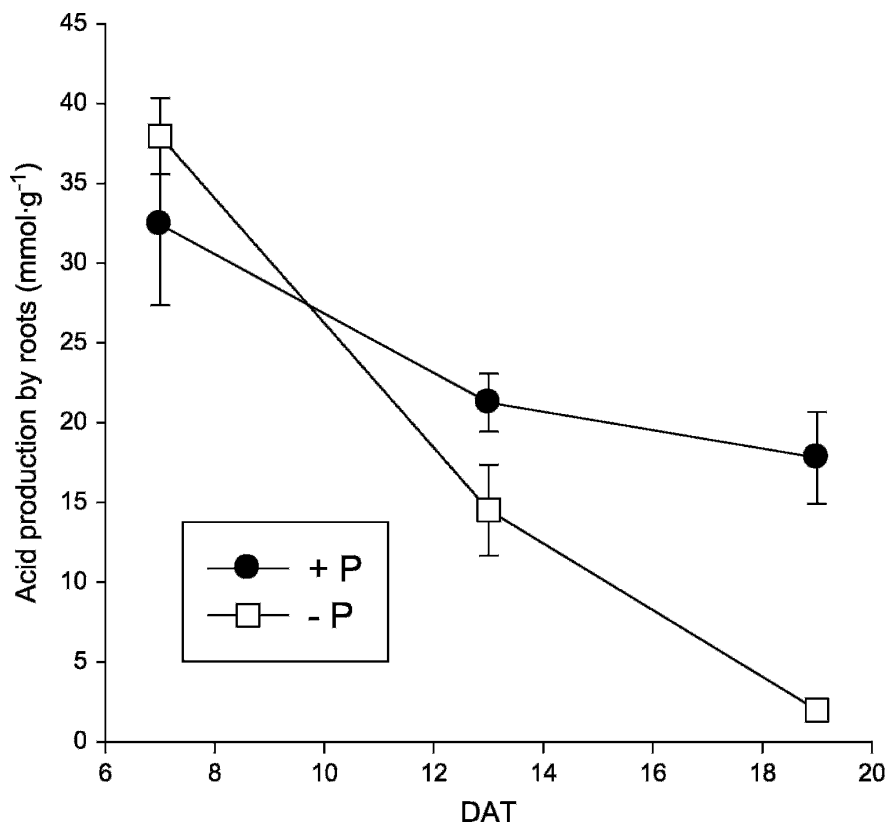

Fig. 5. Acid produced per gram of root dry weight for geranium plants grown with $(+\mathrm{P})$ and without $\mathrm{P}(-\mathrm{P})$ at 7,13 , and $19 \mathrm{~d}$ after transplanting (DAT). Temperature treatments were combined. Error bars represent SE $(n=12)$.

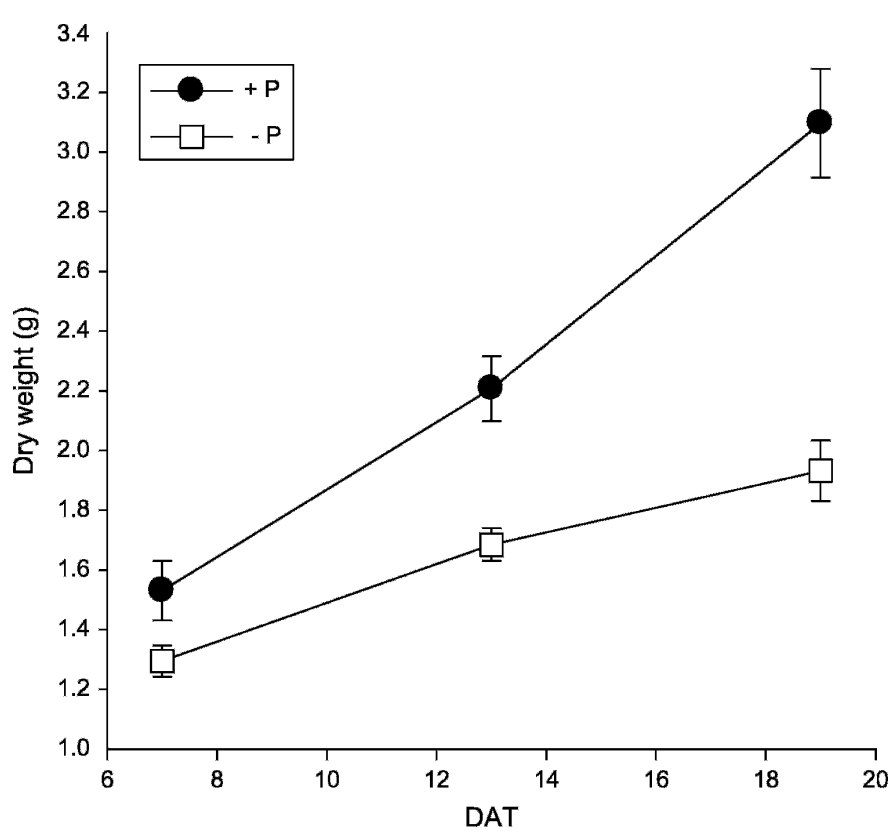

Fig. 6. Whole plant dry weights at 7, 13, and $19 \mathrm{~d}$ after transplanting (DAT) of geranium plants grown with $\mathrm{P}(+\mathrm{P})$ or without $\mathrm{P}(-\mathrm{P})$. Temperature treatments were combined. Error bars represent SE $(n=12)$.

\section{Discussion}

The effect of temperature on growth, development, and flowering of geranium is well documented (White, 1993). Additionally, the results of all three experiments indicate that high temperature increases substrate acidification by geranium. Starting 35 DAT in Expt. 1, substrate pH decreased significantly when tissue $\mathrm{P}$ was deficient $(0.10 \%-0.16 \%)$ and remained relatively constant or increased when tissue $\mathrm{P}$ was close to or above adequate $(0.18 \%-0.34 \%)$ (Fig. 1). Acidification due to $\mathrm{P}$ deficiency is a widespread phenomenon among dicotyledonous species (Marschner, 1995). It was not possible to determine if the $\mathrm{pH}$ effect was due to temperature alone or a combination of temperature and $\mathrm{P}$ deficiency. Increased growth was likely not responsible for increased acidification in the case of 'Designer Dark Red' plants because dry weights of plants from the medium and low temperatures were not statistically different, whereas plants grown at medium temperature had a significantly lower substrate pH starting 56 DAT (Table 1).

In Expt. 2, geranium substrate $\mathrm{pH}$ decreased as temperature increased regardless of tissue $\mathrm{P}$ concentration (Fig. 2). At 28 DAT, tissue $\mathrm{P}$ was adequate in plants at all temperature and $\mathrm{P}$ treatments except $0 \mathrm{P}$. Yet $\mathrm{pH}$ was lower in the high-temperature treatment with all $\mathrm{P}$ rates except the highest. These data indicate temperature acted independent of tissue $\mathrm{P}$ concentration. At 63 DAT, in the 0.065 and $0.13 \mathrm{P}$ treatments, tissue $\mathrm{P}$ was deficient, unaffected by temperature treatment, and $\mathrm{pH}$ decreased with increasing temperature from 5.6 to 4.8 and 5.9 to 4.7 , respectively. At the $0.26 \mathrm{P}$ treatment, tissue $\mathrm{P}$ was adequate at low temperature and was deficient at the two higher temperatures and again $\mathrm{pH}$ decreased as temperature increased. In the highest $\mathrm{P}$ treatment, all tissue $\mathrm{P}$ levels were adequate on both tissue sampling dates, yet at 63 DAT, pH declined from 6.5 at the low temperature to 5.0 at the high temperature. Again, the results at 63 DAT indicate that temperature is acting independent of tissue $\mathrm{P}$. In all cases, when plants received $\mathrm{P}$ and temperature was high, $\mathrm{pH}$ fell below 5.2 by 57 DAT. Dry weights of plants grown at medium and high temperatures were not significantly different 28 DAT and plants grown at high temperature weighed significantly less 63 DAT (Table 4). Because $\mathrm{pH}$ was lower with high temperature on both DAT, these data again indicate that increased growth was not responsible for increased acidification.

Acidification due to P deficiency is also indicated in Expt. 2. When comparing all of the low temperature treatments, substrate $\mathrm{pH}$ decreased when $\mathrm{P}$ was deficient (Fig. 2). In Table 3, plants that received $\mathrm{P}$ and had tissue $\mathrm{P}$ concentration less than the lower established value of $0.17 \%$ to $0.19 \%$ had significantly negative slopes and $r^{2}$ values that indicate a fit of the respective model. Plants grown without $\mathrm{P}$ were severely deficient by 35 DAT, had a $r^{2}$ value that indicated poor fit of the model, and yet still had a significantly negative slope. When plants were grown at low temperature and tissue $\mathrm{P}$ was above $0.19 \%$, the slope was not significantly different from zero and the $r^{2}$ showed that the model fit poorly. This indicates that $\mathrm{P}$ deficiency can cause geraniums to lower substrate $\mathrm{pH}$.

Data in Expt. 3 once again indicated that higher temperatures increase substrate acidification by geranium roots. Acid production per gram root increased $28 \%$ when plants were grown at high temperature compared with the control temperature. The effect of $\mathrm{P}$ treatments on acid production by roots was unexpected. The effect of $\mathrm{P}$ treatment was not 
significant 7 DAT, and plants that received $P$ had increased acid production 13 and 19 DAT (Fig. 5). This was unexpected and may have been due to decreased acidification capacity, caused by severe $\mathrm{P}$ deficiency. Substrate acidification occurs when the net $\mathrm{H}^{+}$efflux from roots increases. The function of the rhizodermal $\mathrm{H}^{+}$ATPase pump is dependent on ATP, which decreases significantly in roots of plants under severe $\mathrm{P}$ stress (Chiera et al., 2004). Shoot $P$ was less than or equal to $0.18 \%$ on the first sampling date (7 DAT) and was severely deficient $(<0.11 \%)$ by 19 DAT in plants not receiving P.

As the treatment temperature increased, the number of irrigations increased for Expts. 1 and 2. Depending on the $\mathrm{pH}$ of the fertilizer solution and the potential acidity/basicity of the fertilizer, increasing the frequency of irrigations could cause substrate $\mathrm{pH}$ to shift upward or downward. The $\mathrm{pH}$ of the fertilizer solution used in Expts. 1 and 2 was 5.6, which is greater than the substrate $\mathrm{pH}$ from nearly all plants grown at medium and high temperature 63 DAT. Additionally, $\mathrm{NO}_{3}$ makes up $80 \%$ or more of the $\mathrm{N}$ in most basic fertilizers (Nelson, 2003). In Expts. 1 and 2, 90\% of the $\mathrm{N}$ was $\mathrm{NO}_{3}^{-}$.

Increased irrigations due to high temperature may also indirectly increase the rate at which lime is leached from the substrate. This may have been a factor in Expt. 1, when the lime source was flowable dolomitic lime that seemed to dissolve slowly over the first 5 weeks of the experiment. This effect was unlikely in Expt. 2. The lime source was readily dissolvable $\mathrm{CaCO}_{3}$ powder that dissolved within the first week. In addition, the data from Expts. 1, 2, and 3, along with the magnitude of the effect on substrate $\mathrm{pH}$ with a small increase in the number of irrigations, indicate that most of the observed effect in these studies was due to a direct effect of high temperature on substrate acidification by geranium. The indirect effect of temperature due to greater lime leaching from increased irrigation frequency is likely a contributing factor to SPD in a commercial setting.

It is clear from this study that high temperature can cause SPD of geraniums. In most cases, when the temperature was high $\left(26{ }^{\circ} \mathrm{C}\right.$ day/22 ${ }^{\circ} \mathrm{C}$ night $)$, substrate $\mathrm{pH}$ dropped 0.5 to 1.3 $\mathrm{pH}$ units within a 2 -week period. The recommended temperatures for the production of zonal geraniums ranges from $18^{\circ} \mathrm{C}$ to $24^{\circ} \mathrm{C}$ for the day and $17{ }^{\circ} \mathrm{C}$ to $22^{\circ} \mathrm{C}$ for the night period (Ball Horticultural Co., 2007; Fischer U.S.A., 2007; Hamrick, 2003). The temperatures used for the high-temperature treatment in this study are just above these recommendations. It is highly likely, during normal geranium production, that temperatures will exceed these recommendations, especially in the southern regions of the United States. To help prevent SPD, geranium growers should avoid P deficiency, which is known to cause substrate acidification, and try to maintain temperature within the recommended range. Although it has been determined that $\mathrm{P}$ deficiency and high temperature are associated with SPD, other factors are most likely involved. Growers need to constantly monitor substrate $\mathrm{pH}$ to head-off possible oncoming $\mathrm{pH}$ problems by using $\mathrm{pH}$ adjustment materials such as flowable limestone.

\section{Literature Cited}

Bachman, G.R. and W.B. Miller. 1995. Iron chelate inducible iron/manganese toxicity in zonal geranium. J. Plant Nutr. 18:19171929.

Ball Horticultural Co. 2007. Ball FloraPlant 2007 catalog. Ball Horticultural Co., Batavia, IL.

Broschat, T. and K. Moore. 2004. Phytotoxicity of several iron fertilizers and their effects on $\mathrm{Fe}, \mathrm{Mn}, \mathrm{Zn}, \mathrm{Cu}$, and $\mathrm{P}$ content of african marigolds and zonal geraniums. HortScience 39:595598.

Cakmak, I. and H. Marschner. 1990. Decrease in nitrate uptake and increase in proton release in zinc deficient cotton, sunflower, and buckwheat plants. Plant Soil 129:261-268.

Chiera, J.M., J.F. Thomas, and T.W. Rufty. 2004. Growth and localized energy status in phosphorus-stressed soybean. J. Plant Nutr. 27:1875-1890.

Fischer, U.S.A. 2007. Producing high quality geraniums, p. 57-74. In: Fischer cultural guide 2007-2008. Fischer USA, Boulder, CO.

Hamrick, D. 2003. Ball redbook. Volume 2: Crop production. 17th ed. Ball Publishing, Batavia, IL.

Hinsinger, P. 2001. Bioavailability of soil inorganic P in the rhizosphere as affected by root-induced chemical changes: A review. Plant Soil 237:173-195.

Krug, B.A., B.E. Whipker, B. Cleveland, and I. McCall. 2006. Taking the "art" out of interpreting tissue analysis for geranium. Proc. Southern Nursery Assn. Res. Conf. 15:635-639.

Landsberg, E. 1981. Organic acid synthesis and release of hydrogen ions in response to Fe deficiency stress of mono- and dicotyledonous plant species. J. Plant Nutr. 3:579-591.

Lee, C.W., J.M. Choi, and C.H. Pak. 1996. Micronutrient toxicity in seed geranium $($ Pelargonium $\times$ hortorum Bailey). J. Amer. Soc. Hort. Sci. 121:77-82.

Marschner, H. 1995. Mineral nutrition of higher plants. Academic Press, New York.

Naegle, E.R., J.W. Burton, T.E. Carter, and T.W. Rufty. 2005. Influence of seed nitrogen content of seedling growth and recovery form nitrogen stress. Plant Soil 271:329-340.

Nelson, P.V. 2003. Greenhouse operation and management. 6th ed. Prentice Hall, Upper Saddle River, NJ.

Schjorring, J.K. 1986. Nitrate and ammonium absorption by plants growing at a sufficient or insufficient level of phosphorus in nutrient solution. Plant Soil 91:313-318.

Smith, B.R., P.R. Fisher, and W.R. Argo. 2004. Water-soluble fertilizer concentration and $\mathrm{pH}$ of a peat-based substrate affect growth, nutrient uptake, and chlorosis of container-grown seed geraniums. J. Plant Nutr. 27:497-524.

Taylor, M.D., P.V. Nelson, J.M. Frantz, and T.W. Rufty. 2007. Effect of phosphorus deficiency and high temperature on ammonium and nitrate uptake and acidification by Pelargonium. HortScience 42:890. (Abstr.).

U.S. Department of Agriculture. 2005. Floriculture crop summary. U.S. Dept. Agr., Natl. Agr. Stat. Serv. Spec. Circ. 6-1(05).

Welkie, G.W. and G.W. Miller. 1993. Plant iron uptake physiology by nonsiderophore systems, p. 345-369. In: L.L. Barton and B.C. Hemming (eds.). Iron chelation in plants and soil microorganisms. Academic Press, New York.

White, J.W. 1993. Geraniums IV. The grower's manual. Ball Publishing, Batavia, IL.

Wright, R.D. 1986. The pour-through nutrient extraction procedure. HortScience 21:227-229. 